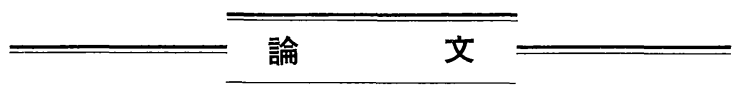

農業気象(J.Agr. Met.) 31(3): 115-124, 1975

\title{
Micrometeorology and Assessment of Primary Production of a Tropical Rain Forest in West Malaysia.*
}

\author{
Masatoshi AOKI**, Kazutoshi YABUKI**, Hiromichi KoYAMA*** \\ (** College of Agriculture, University of Osaka Prefecture, Mozu, Sakai, Osaka, T591) \\ (*** Botanical Garden, Faculty of Science, Osaka City University, Katano, Osaka, T576)
}

\begin{abstract}
The micrometeorology and the primary production of a lowland tropical rain forest at Pasoh, West Malaysia were studied.

About $50 \%$ of incoming solar radiation was diminished by the upper $5 \mathrm{~m}$ layer of canopy and only $3 \%$ reached the ground surface. The diurnal range of air temperature was small and humidity was higher than $90 \%$ throughout the day near ground. The upward water vapour transfer from the canopy to the atmosphere was observed even at night. This seemed to be related to the formation of night fog. Because the leaf area density of the forest was small, the gradients of air temperature, water vapour pressure, and carbon dioxide concentration in the forest were also small.

The net canopy photosynthesis was about $43 \mathrm{mgCO}_{2} \cdot 100 \mathrm{~cm}^{-2} \cdot \mathrm{hr}^{-1}$ when incoming solar radiation was $1.3 \mathrm{cal} \cdot \mathrm{cm}^{-2} \cdot \mathrm{min}^{-1}$. The annual gross production of the forest was estimated at 81 ton D.W.ha ${ }^{-1} \cdot \mathrm{year}^{-1}$ and the efficiency of solar energy conversion for it was $3.0 \%$.
\end{abstract}

\section{Introduction}

\section{Method}

The micrometeorology of tropical rain forests has been studied by Hales (1949), Baynton and et al. (1965a, 1965b), Lemon et al. (1970), and Allen et al. (1972). The primary production rates of forests under natural conditions have been estimated by various micrometeorological techniques. Baumgartner (1969) in a spruce forest of Munich and Lemon et al. (1970) in a tropical rain forest of Costa Rica used the aerodynamic method. Yabuki and Aoki (1973) in an evergreen oak forest of Japan used the traverse method for this purpose.

The present work was carried out to reveal the micrometeorological environment in a lowland rain forest in Pasoh Forest Reserve, West Malaysia, a study area of the International Biological Program (IBP).

Read at the Autumn Meeting, Osaka, Oct. 31st, 1974.

Received on August 9th, 1975.

* Japanese Contribution NO. 4, IBP Pasoh Forest Project, supported by the Japan Society for the Promotion of Science.

\section{1. $\mathrm{CO}_{2}$ budget of forest}

The $\mathrm{CO}_{2}$ budget for a forest is illustrated in Fig. 1. In the daytime, $\mathrm{CO}_{2}$ flux is oriented downward from the atmosphere $\left({ }_{d} C_{a}\right)$, upward from the ground $\left({ }_{d} C_{S}\right)$, and horizontally to the stand by advection $\left(C_{h}\right) . C_{h}$ may be neglected in the present case, since the observation point was located at about $1 \mathrm{~km}$ from the border of the forest. Thus we can write net uptake of $\mathrm{CO}_{2}\left({ }_{d} P_{n}\right)$ or net photosynthesis in the daytime as follows:

$$
{ }_{d} P_{n}={ }_{d} C_{a}+{ }_{d} C_{s}
$$

The gross uptake of $\mathrm{CO}_{2}\left({ }_{d} P_{g}\right)$ or the gross photosynthesis rate is

$$
{ }_{d} P_{g}={ }_{d} C_{a}+{ }_{d} C_{s}+{ }_{d} C_{r}
$$

where ${ }_{d} C_{r}$ is rate of plant respiration in the daytime. The $\mathrm{CO}_{2}$ balance at the canopy surface at night is 


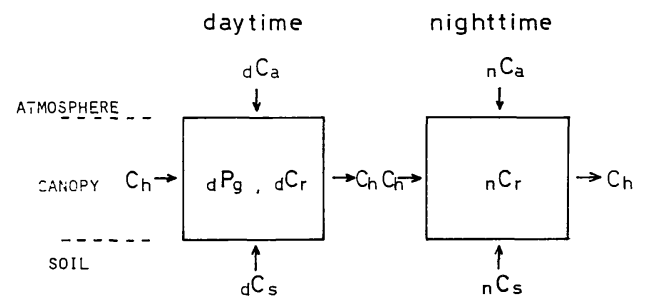

Fig. $1 \mathrm{CO}_{2}$ budget in a plant stand.

$C_{a}, \mathrm{CO}_{2}$ flux above forest; $C_{r}$, rate of $\mathrm{CO}_{2}$ released by respiration of plants; $C_{S}$, rate of $\mathrm{CO}_{2}$ release from ground surface; $P_{g}$, rate of gross photosynthesis; $C_{h}, \mathrm{CO}_{2}$ flux by advection. Prefixes $d$ and $n$ denote daytime and nighttime.

$$
{ }_{n} C_{a}={ }_{n} C_{r}+{ }_{n} C_{s}
$$

where ${ }_{n} C_{a},{ }_{n} C_{r}$, and ${ }_{n} C_{s}$ are $\mathrm{CO}_{2}$ flux to the atmosphere at the canopy surface, rate of $\mathrm{CO}_{2}$ release by respiration of plants, and rate of $\mathrm{CO}_{2}$ release from ground surface respectively at night. If the soil respiration is known, we can get the rates of canopy photosynthesis and plant respiration from the $\mathrm{CO}_{2}$ flux above canopy using equations (1) through (3).

\section{2. $\mathrm{CO}_{2}$ flux above canopy}

The $\mathrm{CO}_{2}$ flux $\left(C_{a}\right)$ is given as

$$
C_{a}=D_{c}\left(C_{1}-C_{2}\right)
$$

where $C_{1}$ and $C_{2}$ are $\mathrm{CO}_{2}$ concentrations at heights of $z_{1}$ and $z_{2}$ respectively, and $D_{c}$ is exchange velocity for $\mathrm{CO}_{2}$.

Under the assumption that $D_{c}$ is equal to both the exchange velocities for water vapour and for heat, $D_{c}$ is written as follows:

$$
D_{c}=\frac{S_{H}-(B+G)}{\rho \cdot l(1+\beta)\left(q_{1}-q_{2}\right)}
$$

and

$$
\beta=\frac{C_{p}}{l} \frac{\left(T_{1}-T_{2}\right)}{\left(q_{1}-q_{2}\right)} \quad \text { (Bowen's ratio) - }
$$

where $S_{H}$ : net radiation received by unit horizontal surface area above canopy

$G$ : storage heat in biomass

$B$ : heat flux in soil

$C_{p}: \quad$ specific heat of air $\left(=0.24 \mathrm{cal} \cdot \mathrm{g}^{-1} \cdot{ }^{\circ} \mathrm{C}^{-1}\right)$

$\rho:$ density of air $\left(=1.29 \times 10^{-3} \mathrm{~g} \cdot \mathrm{cm}^{-3}\right)$ $l$ : latent heat of vapourization

$$
\left(=590 \mathrm{cal} \cdot \mathrm{g}^{-1}\right)
$$

$T$ : air temperature

$q:$ specific humidity

suffixes 1,2: height levels

With eq. (5), eq. (4) can be written as

$$
C_{a}=\frac{S_{H}-(B+G)}{\rho \cdot l(1+\beta)\left(q_{1}-q_{2}\right)}\left(C_{1}-C_{2}\right)
$$

Provided $B=0$, one can simplify eq. (7) as

$$
C_{a}=\frac{S_{H}-G}{\rho \cdot l(1+\beta)\left(q_{1}-q_{2}\right)}\left(C_{1}-C_{2}\right)
$$

This assumption is permissible in the case of this forest because the incoming solar radiation at the soil surface in the forest was about $3 \%$ of that above canopy and the diurnal range of soil surface temperature was only $2^{\circ} \mathrm{C}$.

\section{Soil respiration}

The annual mean soil respiration rate was estimated by Ogawa (1974) at $6 \mathrm{mgCO}_{2} \cdot 100 \mathrm{~cm}^{-2} \cdot \mathrm{hr}^{-1}$ in Pasoh Forest. Besides, an additional flux of $\mathrm{CO}_{2}$ of $2.4 \mathrm{mgCO}_{2}$. $100 \mathrm{~cm}^{-2} \cdot \mathrm{hr}^{-1}$ entered the atmosphere through the decomposition of big wood litter (Yoneda et al. 1975). $C_{S}$ was thus taken as $8.4 \mathrm{mgCO} \cdot 100 \mathrm{~cm}^{-2} \cdot \mathrm{hr}^{-1}$. To be exact, root respiration must be separated from soil respiration. But it is included in the soil respiration, and we assumed that the soil respiration in the daytime was equal to that at night.

\section{Storage heat in biomass}

The storage heat in biomass can be usually omitted in crop stands. However, it should be taken into account in the heat balance for the forest. The fresh weight of boimass of this forest is about 800 ton $\cdot \mathrm{ha}^{-1}$ (or $8 \mathrm{~g} \cdot \mathrm{cm}^{-2}$ ). When we assume that the diurnal range of biomass temperature is $8^{\circ} \mathrm{C}$, the amount of the storage heat in biomass $(G)$ is about $32 \mathrm{cal} \cdot \mathrm{cm}^{-2}$ during a half of the daytime and is equivalent to about $20 \%$ of incoming net radiation.

Since the estimation of the amount of storage heat is difficult, we calculated $C_{a}$ for two cases by eq. (8). In the first case, $G$ was assumed to be equal to zero. In the second case, we calculated $G$, assuming that the biomass temperature followed the air temperature. The first case gives the minimum of $G$, and the second estimates its 
maximum.

\section{Site and measurements}

Measurements were carried out near the center of the IBP study area in Pasoh Forest Reserve, Negeri Sembilan, West Malaysia $\left(2^{\circ} 59^{\prime} \mathrm{N}\right.$ and $\left.102^{\circ} 18^{\prime} \mathrm{E}\right)$. It is located about $140 \mathrm{~km}$ southeast of Kuala Lumpur, the capital of Malaysia. The area is a $2 \mathrm{~km}$ by $3 \mathrm{~km}$ (650ha) more or less flat terrain. Pasoh Forest Reserve is one of the representative lowland rain forests in West Malaysia. The overtopping trees of the forest is $45-55 \mathrm{~m}$ high. The leaf area index (LAI) is about 8 (Kato et al., 1974). A general description of the forest was given by Soepadmo (1973).

Instruments were mounted on a $36 \mathrm{~m}$ high wood tower and pole along the trunk of a $47 \mathrm{~m}$ tall Shorea leprosula tree. The top of the pole was $53 \mathrm{~m}$. It was tall enough to obtain the log-profile of wind speed above canopy. Thus it was presumably high enough for the measurement of $\mathrm{CO}_{2}$ flux also.

Fig. 2 shows a schematic diagram of installation of the instruments. Dry and wet bulb temperatures were measured at eight levels with ventilated copper-constantan thermocouples in double-shielded nozzles. Water for wet bulbs was pumped up from the top floor of the tower by small plastic tubes. The outputs from these thermometers were led to a 24-channel scanner, and

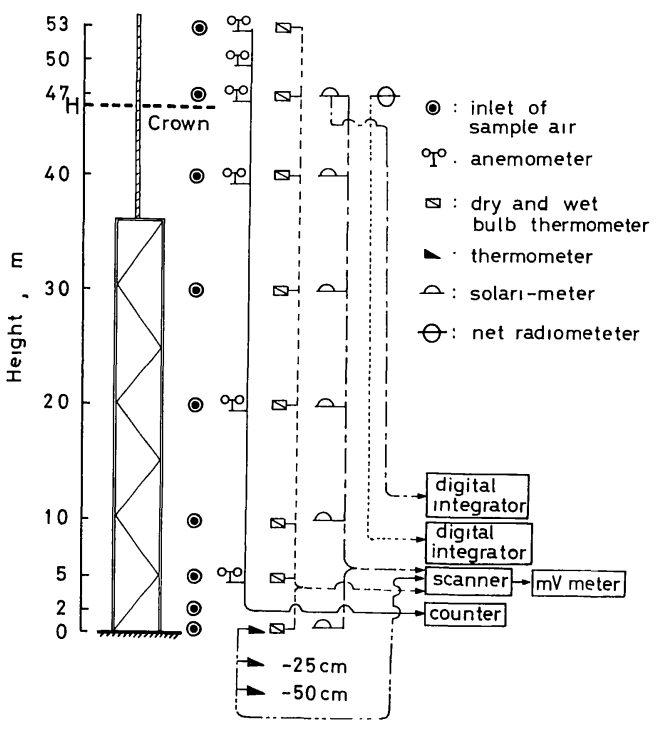

Fig. 2 Schematic diagram of the installation for the measurements. read by a milli-volt meter. The wind speed was measured with six cup-anemometers. The starting wind speed of the anemometers was $10 \mathrm{~cm} \cdot \mathrm{sec}^{-1}$, sensitive enough to be used within the forest even at night. The pulse signals from the anemometers were counted by a six-channel counter. Solar radiation was measured at six levels by six solarimeters. Net radiation above the canopy was measured by a Funk type net radiometer. The output of lower five solarimeters were read by a milli-volt meter. The outputs of the top solarimeter and the net radiometer were led to two digital intergrators. The air for measurement of $\mathrm{CO}_{2}$ concentration was sampled at nine levels through plastic tubes. When the absolute concentration was needed, the sample air was first collected into plastic bags and then analyzed by an absolute type infrared $\mathrm{CO}_{2}$ analyzer (600 ppm full scale). It took about 90 minutes to bring bags from the measurement site to the analyzer site by car. To calculate the $\mathrm{CO}_{2}$ flux, air samples from two levels above canopy were led directly into the cells of a differential type infrared $\mathrm{CO}_{2}$ analyzer, installed near the measurement site, through plastic tubes.

Two or three readings of all meteorological elements were taken in ten minutes at the beginning of each hour and were averaged to obtain the diurnal courses of micrometeorological conditions in the forest. When the $\mathrm{CO}_{2}$ flux was measured, all the meteorological elements above canopy were measured at every five minutes in addition to the hourly measurement, and the data thus obtained were averaged over 25 minutes.

The whole day measurement was done on Nov. 7 8, on Nov. $14 \sim 15$, and on Nov. $21 \sim 22,1973$. The $\mathrm{CO}_{2}$ fluxes above forest were measured on Nov. $19 \sim 21$, 1973. On Nov. 21 and 22, the weather conditions were typical of the region and all the meteorological data were completely collected.

\section{Results and discussion}

\section{Micrometeorology of the rain forest}

(1) Solar radiation and net radiation

The diurnal variations of incoming solar radiation and net radiation are shown in Fig. 3-a. The maximum solar radiation and net radiation were $1.2 \mathrm{cal} \cdot \mathrm{cm}^{-2} \cdot \mathrm{min}^{-1}$ and $0.9 \mathrm{cal} \cdot \mathrm{cm}^{-2} \cdot \mathrm{min}^{-1}$ respectively on Nov. 21 . The profile of relative solar radiation within the forest is shown in Fig. 4. 

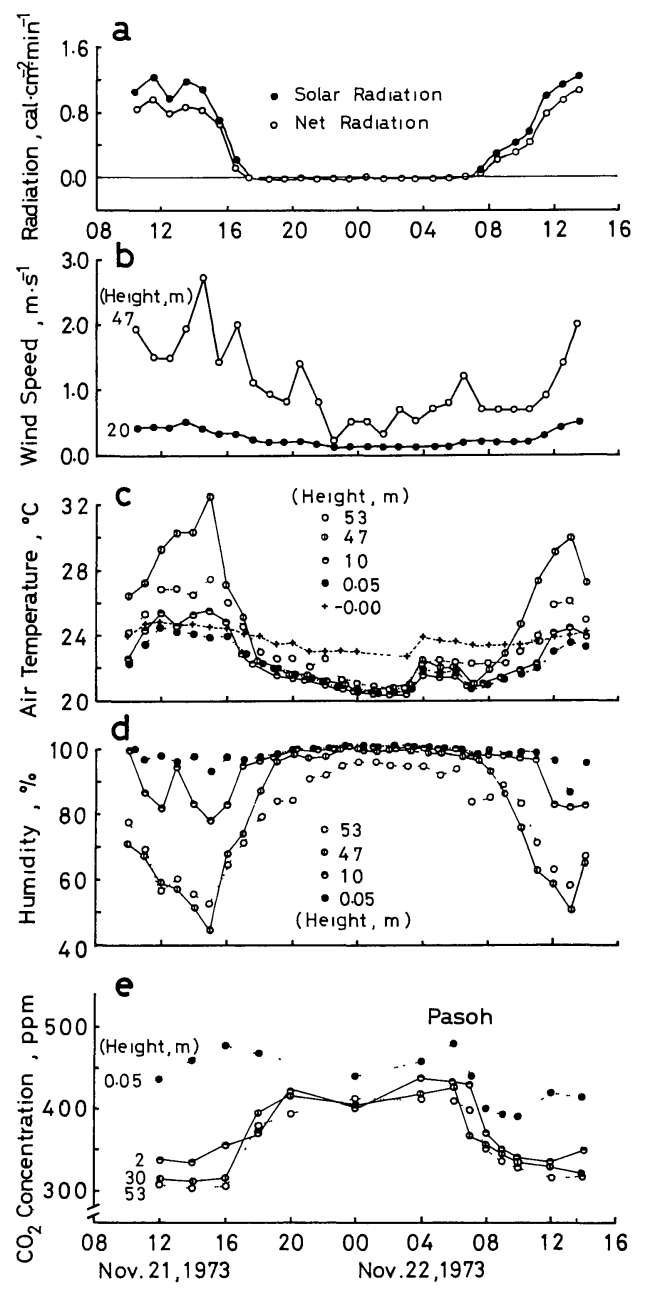

Fig. 3 Diurnal courses of environmental elements.

a: solar radiation and net radiation above forest.

b: wind speed at $47 \mathrm{~m}$ and $20 \mathrm{~m}$.

c: air temperature. d: relative humidity.

e: $\mathrm{CO}_{2}$ concentration.

About $50 \%$ of incoming solar radiation was diminished by the upper $5 \mathrm{~m}$ layer of the crown and only $3 \%$ reached the ground surface. The solar radiation decreased exponentially with depth from the top of canopy, and the following relationship roughly fitted the data.

$$
\begin{gathered}
I_{z}=I_{H} e^{-k\left(1-\frac{z}{H}\right)} \\
k=2.67
\end{gathered}
$$

where $I_{z}$ and $I_{H}$ are solar radiation values at heights $z$ and $H$ (the height of stand) respectively, $k$ is the extinction coefficient for solar radiation. Relatively small

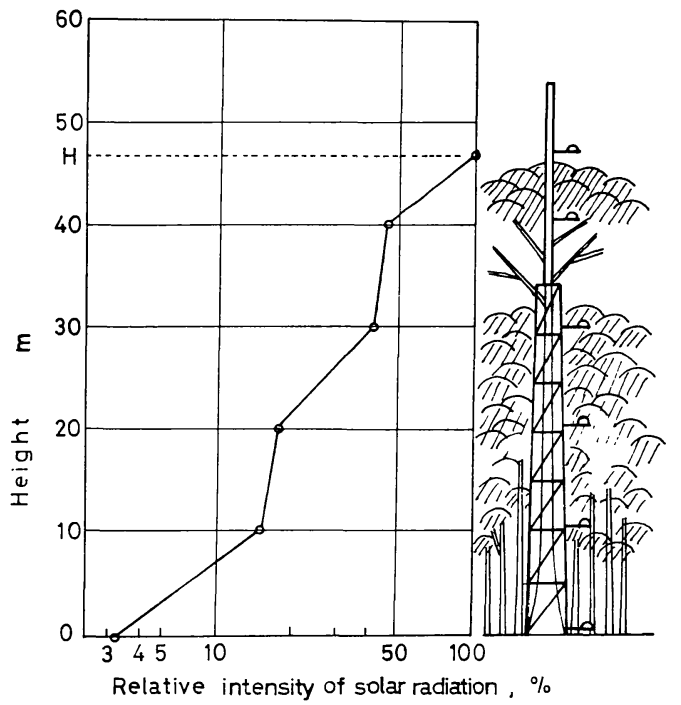

Fig. 4 Profile of solar radiation in the forest. The data are mean values for 5 days. $H$ denotes the height of stand.

decrease in solar radiation in the layers of $30 \mathrm{~m}-40 \mathrm{~m}$ and $10 \mathrm{~m}-20 \mathrm{~m}$ appears to be corresponding to the smaller leaf area densities in these layers. Yoda (1974) made more detailed measurements of the light intensity profile in the same study area and obtained a similar profile to that in this observation. The extinction coefficient obtained here is nearly equal to that in the evergreen oak forest of Japan $(k=2.92)$ (Yabuki and Aoki, unpublished).

The net radiation was about $80 \%$ of solar radiation. At night, the net loss of long wave radiation was less than $0.01 \mathrm{cal} \cdot \mathrm{cm}^{-2} \cdot \mathrm{min}^{-1}$. We supposed that the exchange of the long wave radiation between forest and atmosphere decreased owing to the fog which had appeared in the lower atmosphere above forest at night. The phenomenon will be discussed later.

The relationship between incoming solar radiation $\left(I_{H}\right)$ and net radiation above forest $\left(S_{H}\right)$ was expressed by the following formula with a correlation coefficient of 0.99 (Fig. 5):

$$
S_{H}=0.79 I_{H}-0.01 \mathrm{cal} \cdot \mathrm{cm}^{-2} \cdot \mathrm{min}^{-1}
$$

\section{(2) Air temperature and humidity}

The diurnal courses and the isopleths of air temperatures in and above forest are shown in Fig. 3-c and Fig. 6-a respectively. The maximum air temperature 


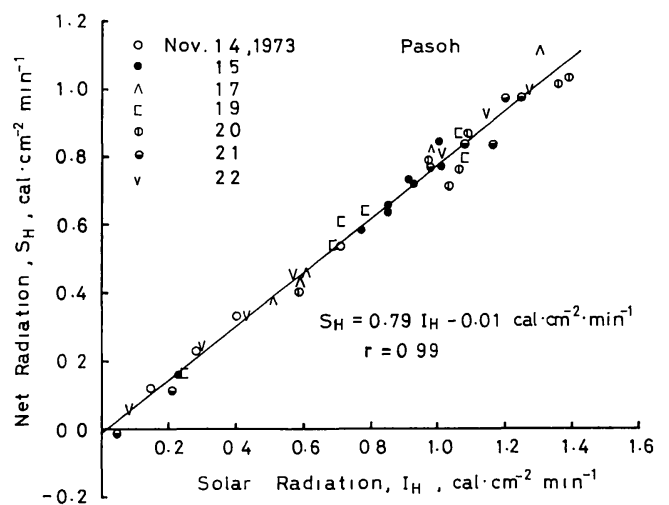

Fig. 5 Relation between solar radiation and net radiation above forest.

$r$ denotes the correlation coefficient.

always appeared at the top of canopy, $47 \mathrm{~m}$ high above the ground. At night, the air temperature is fairly evenly distributed within the stand space $\left(20 \sim 22^{\circ} \mathrm{C}\right)$. The minimum air temperature was seen in the middle layer of forest. The average maximum air temperatures at $53 \mathrm{~m}$ and $47 \mathrm{~m}$ were about $29^{\circ} \mathrm{C}$ and about $32^{\circ} \mathrm{C}$, while those at $10 \mathrm{~m}$ and at $0.05 \mathrm{~m}$ were about $26^{\circ} \mathrm{C}$ and $25^{\circ} \mathrm{C}$ respectively. The difference of the maximum air temperature between the canopy top and the ground was $6 \sim 11^{\circ} \mathrm{C}$ (Table 1 ). The daily average air temperatures were almost equal for both $40 \mathrm{~m}$ and $0.05 \mathrm{~m}$ heights. The diurnal range of air temperature at the canopy top was about $10^{\circ} \mathrm{C}$. Near the ground it was only $4^{\circ} \mathrm{C}$, or about $40 \%$ of that at the canopy top (Table 2). The decreases in the maximum and the daily range of air temperature inside forest may be caused by the decrease of incoming radiation as seen in Fig. 4. The mean diurnal temperature range at the soil surface was only $2^{\circ} \mathrm{C}$.

The diurnal variations and isopleth of relative humidity (Fig. 3-d and Fig. 6-b) were nearly reverse to those

Table 1 Maximum air temperatures in and above forest.

\begin{tabular}{rccccccc}
\hline $\begin{array}{c}\text { HEIGHT } \\
(\mathrm{m})\end{array}$ & \multicolumn{7}{c}{ MAXIMUM AIR TEMPERATURE $\left({ }^{\circ} \mathrm{C}\right)$} \\
& Nov.14 & Nov.15 & Nov.19 & Nov.20 & Nov.21 & Nov.22 & MEAN \\
\hline 53 & 30.1 & 30.1 & 31.1 & 30.7 & 27.4 & 26.1 & 29.3 \\
47 & 30.3 & 32.3 & 32.0 & 36.3 & 32.5 & 30.0 & 32.2 \\
40 & 24.7 & 28.2 & 27.5 & 29.4 & 26.7 & 25.6 & 27.0 \\
30 & 24.8 & 28.6 & 27.8 & 29.0 & 26.6 & 25.8 & 27.1 \\
20 & 25.0 & 28.5 & 27.8 & 28.1 & 26.5 & 24.8 & 26.8 \\
10 & 24.5 & 27.4 & 26.3 & 26.8 & 25.5 & 24.5 & 25.8 \\
0.05 & 24.5 & 25.4 & 25.5 & 25.4 & 24.5 & 23.6 & 24.8 \\
-0.00 &.--- & 24.5 & $\ldots .-$ &..-- &.--- & 24.0 & 24.3 \\
\hline
\end{tabular}

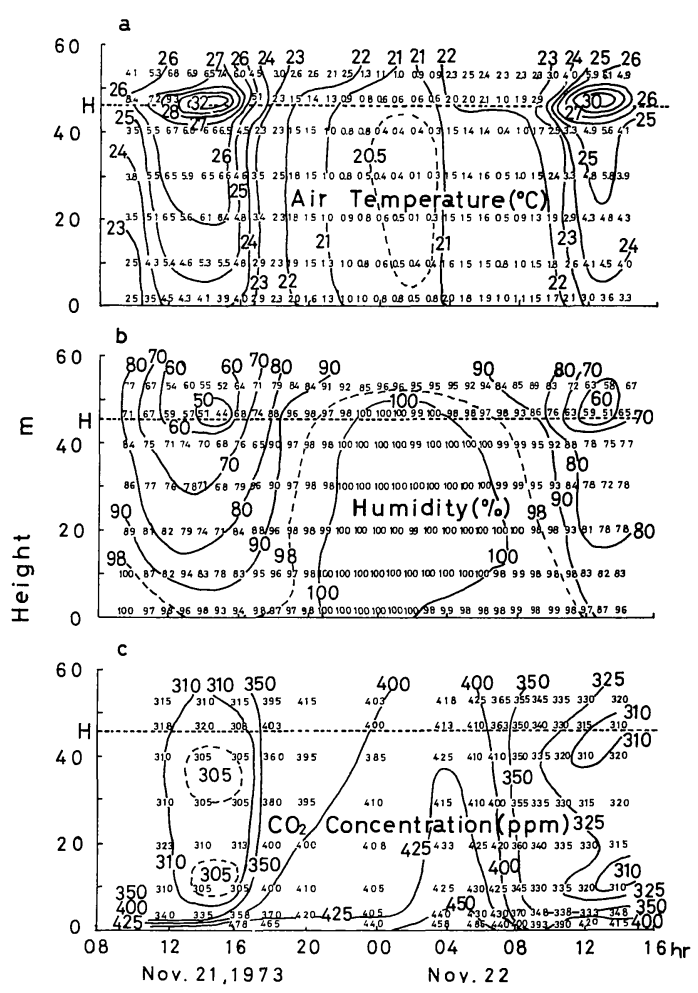

Fig. 6 Isopleths of air temperature, humidity and $\mathrm{CO}_{2}$ concentration.

a: air temperature. Numerals in small figures have to be added to $20^{\circ} \mathrm{C}$ for air temperature.

$\mathrm{b}$ : relative humidity. c: $\mathrm{CO}_{2}$ concentration.

of air temperature, with the minimum humidity (50\%) at the canopy surface in the afternoon and the nearly saturated condition throughout the night at all heights. Near the soil surface humidity was high, dropping below $95 \%$ only for a few hours in the afternoon.

The isopleth of water vapour pressure is shown in Fig. 7. Fig. 8 gives the profiles of water vapour pressure within canopy. Not only in the daytime but also at

Table 2 Maximum and minimum air temperatures in and above forest.

\begin{tabular}{rrrrrr}
\hline \multirow{2}{*}{$\begin{array}{c}\text { HEIGHT } \\
(\mathrm{m})\end{array}$} & \multicolumn{4}{c}{ AIR TEMPERATURE $\left({ }^{\circ} \mathrm{C}\right)$} \\
& Nov.15 & \multicolumn{2}{c}{ Nov.22 } & MEAN RANGE \\
& max. & min. & max. & min. & \\
\hline 53 & 30.1 & 21.2 & 26.1 & 20.9 & 7.1 \\
47 & 32.3 & 20.9 & 30.0 & 20.6 & 10.4 \\
40 & 28.2 & 20.7 & 25.6 & 20.3 & 6.4 \\
30 & 28.6 & 20.6 & 25.8 & 20.1 & 6.9 \\
20 & 28.5 & 20.3 & 24.8 & 20.1 & 6.5 \\
10 & 27.4 & 20.6 & 24.5 & 20.4 & 5.5 \\
0.05 & 25.4 & 20.8 & 23.6 & 20.5 & 3.9 \\
-0.00 & 24.5 & 22.0 & 24.0 & 22.7 & 1.9 \\
\hline
\end{tabular}




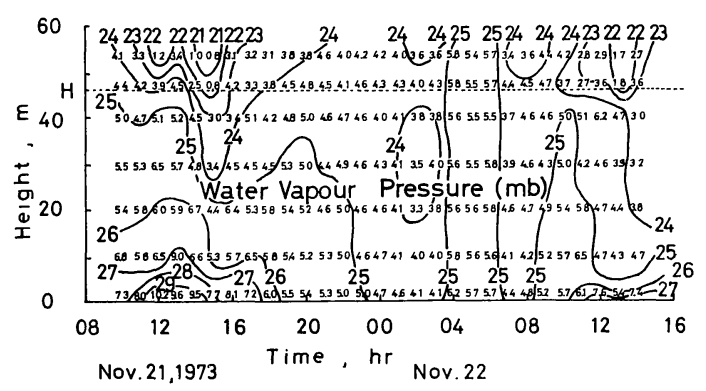

Fig. 7 Isopleth of water vapour pressure in forest. Numerals in small figures have to be added to $20 \mathrm{mb}$ for water vapour pressure.

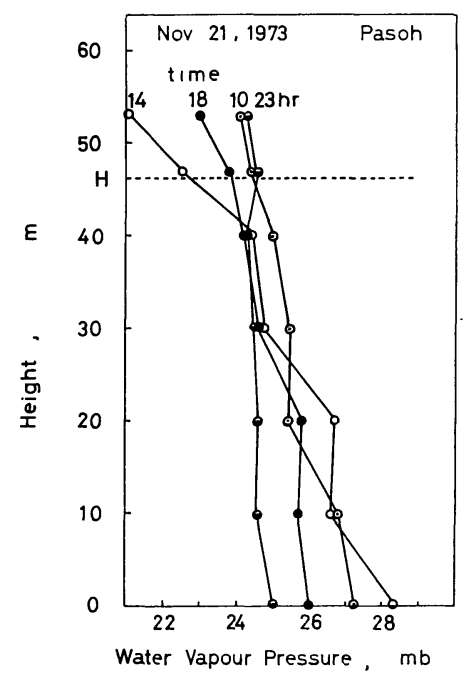

Fig. 8 Vertical distribution of water vapour pressure in forest.

night, the water vapour pressure at the top of canopy was higher than that of the atmosphere above canopy. This means that water vapour was transferred from the forest to the atmosphere even at night. The night fog in the lower atmosphere above forest might be fed by the water vapour from forest.

The gradients of air temperature and water vapour pressure in the forest were much smaller than those in other types of vegetation. The ratios of the gradients of air temperature and of water vapour pressure in this forest to those in a sunflower community (Eckardt et al., 1971) were about one-third and one-fourteenth respectively. Since the average leaf area density of Pasoh Forest is about $11 \%$ of that of the sunflower community, the extremely small gradients of both water vapour pres- sure and air temperature in this forest may be caused mainly by the small leaf area density.

(3) Heat flow in forest

During daytime, the air temperature in the upper part of canopy which diminished about 50\% of incoming solar radiation was the highest. Then the sensible heat flux was from the upper part of canopy to the atmosphere and to the inner part. The water vapour pressure decreased with the increase in height from the ground. Therefore, the latent heat flowed from the inner part of canopy to the atmosphere. After sunset, the radiative cooling occurred in the upper layer and then the air temperature in the upper layer was the lowest. Therefore, this layer became the sink of sensible heat. On the other hand, the vapour pressure still decreased as the height increased. At midnight, the cooling layer moved to the inner layer of canopy. The latent heat still flowed from the inner layer to the atmosphere, although the magnitude became much smaller. In general, the radiative cooling occurs in the upper layer of dense vegetation at clear night. Hosker et al. (1974), for example, observed that the cooling layer existed in the upper half of a $17 \mathrm{~m}$ tall dense pine plantation in Oak Ridge, Tennessee, U.S.A. In Pasoh Forest, however, there was the cooling layer at an intermediate height in the stand. After sunset, the upward water vapour flux continued to carry latent heat from the layers inside canopy to the air layer above canopy where condensation (fog formation) took place owing to radiative cooling. The fog thus formed would grow thicker till midnight, depressing the radiative cooling at the surface. Therefore, the coolest layer would develop inside the canopy as the above processes continued.

(4). Wind speed

Fig. 9-c gives the profile of wind speed in the forest. The diurnal courses of wind speed at two levels in the forest are shown in Fig. 3-b. The wind speed profiles were similar to those in other types of vegetation, 'but the zero-plane displacement, $40 \sim 45 \mathrm{~m}$, was larger.

To understand the character of wind speed profile in the forest we compared it with those in rice communities (Fig. 10). The relative wind speed in the forest is about two times greater than that in the rice fields, of which leaf area densities (LAD) were $3.80 \mathrm{~m}^{2} \cdot \mathrm{m}^{-3}(H=92 \mathrm{~cm})$ and $3.63 \mathrm{~m}^{2} \cdot \mathrm{m}^{-3}(H=110 \mathrm{~cm})$. This difference may be due to the smaller leaf area density in this forest 


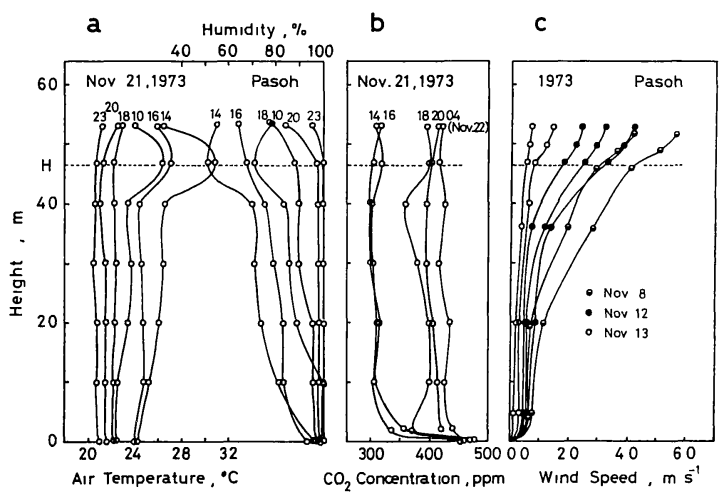

Fig. 9 Profiles of air temperature, relative humidity, $\mathrm{CO}_{2}$ concentration and wind speed in and above forest.

a: air temperature and relative humidity,

b: $\mathrm{CO}_{2}$ concentration. c: wind speed.

$\left(\mathrm{LAD}=0.170 \mathrm{~m}^{2} \cdot \mathrm{m}^{-3}\right)$. The best fit formula for the wind profile, except near ground, is

$$
\frac{U_{z}}{U_{H}}=\left(1-\frac{U_{0}}{U_{H}}\right) e^{-\alpha\left(1-\frac{z}{H}\right)}+\frac{U_{0}}{U_{H}}
$$

where $U_{0}$ denotes the extrapolated wind speed at the ground from the data in the upper layers, and $\alpha$ is the extinction coefficient of wind speed. This formula also fits the wind profiles in paddy fields (Fig. 10) and a corn field obtained by Stoller and Lemon (1963). This result indicates the two wind regimes inside canopy as Takeda (1964) has theoretically suggested. In this forest, $U_{0} / U_{H}=0.17$ and $\alpha=2.85$. The constant $\alpha$ for this forest was about a half that for the paddy fields.

\section{(5) Carbon dioxide concentration}

Diurnal courses of carbon dioxide concentration are shown in Fig. 3-e. The concentration was always greater than $400 \mathrm{ppm}$ on the ground and surpassed 450ppm at night. Between 0800hr and 1200hr, it dropped to 305 $310 \mathrm{ppm}$ at the $5-53 \mathrm{~m}$ layer. It began to increase again after $1600 \mathrm{hr}$. The average $\mathrm{CO}_{2}$ concentrations ranged

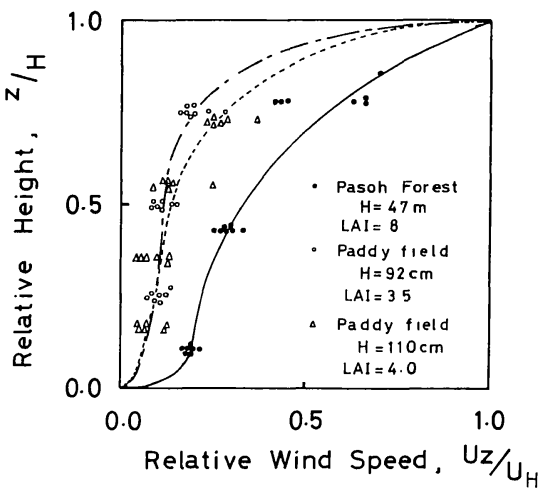

Fig. 10 Profiles of relative wind speed in forest and paddy fields. The data for paddy fields were cited from Yabuki et al. (1974), and LAI of Pasoh Forest from Kato et al. (1974).

from 310 to $420 \mathrm{ppm}, 310$ to $430 \mathrm{ppm}, 340$ to $450 \mathrm{ppm}$, and 390 to $510 \mathrm{ppm}$ at $53 \mathrm{~m}, 30 \mathrm{~m}, 2 \mathrm{~m}$, and $0.05 \mathrm{~m}$ respectively. The average diurnal range was $110 \sim$ 120 ppm for all heights (Table 3).

The difference in $\mathrm{CO}_{2}$ concentration between the upper and middle layer of the forest was about $5 \mathrm{ppm}$ in the daytime. Baumgartner (1969) in a spruce forest in Germany, Allen et al. (1972) in a tropical rain forest in Costa Rica, and Yabuki and Aoki (1973) in an evergreen oak forest in Japan reported about the same difference of $5 \mathrm{ppm}$. Therefore, the daytime decrease of $\mathrm{CO}_{2}$ concentration in forests appears to be about $5 \mathrm{ppm}$ on fine day, which is smaller than that in crop communities.

Profiles of $\mathrm{CO}_{2}$ concentration are drawn in Fig. 9-b. The concentration gradient was very small except near the ground as compared with that in crop communities. The maximum gradient in the daytime between the top and the middle layer of canopy was about $20 \mathrm{ppm} / 25 \mathrm{~m}$ $\left(=0.8 \mathrm{ppm} \cdot \mathrm{m}^{-1}\right)$. The maximum gradients in dense stands of maize (stand height, $H=225 \mathrm{~cm}$ ) and of wheat $(H=35 \mathrm{~cm})$ at noon on fine days were about $15 \mathrm{ppm} /$

Table 3 Maximum and minimum $\mathrm{CO}_{2}$ concentrations in and above forest.

\begin{tabular}{|c|c|c|c|c|c|c|c|c|c|c|c|}
\hline \multirow{3}{*}{$\begin{array}{l}\text { HEIGHT } \\
\text { (m) }\end{array}$} & \multicolumn{8}{|c|}{$\mathrm{CO}_{2}$ CONCENTRATION (ppm) } & \multirow{2}{*}{\multicolumn{3}{|c|}{$\begin{array}{c}\text { AVERAGE } \\
\text { (Nov.8, Nov. } 15 \text {, Nov.22) }\end{array}$}} \\
\hline & \multicolumn{2}{|c|}{ Nov. 8} & \multicolumn{2}{|c|}{ Nov. 15} & \multicolumn{2}{|c|}{ Nov. 21} & \multicolumn{2}{|c|}{ Nov. 22} & & & \\
\hline & $\min$. & $\max$. & $\min$. & $\max$. & $\min$. & $\max$. & $\min$. & $\max$. & $\min$. & $\max$. & range \\
\hline 53 & 300 & 420 & 320 & 400 & 310 & $-\ldots$ & 320 & 430 & 310 & 420 & 110 \\
\hline 30 & 310 & 430 & 315 & 425 & 305 & $\cdots$ & 315 & 420 & 310 & 430 & 120 \\
\hline 20 & 305 & 435 & 315 & 425 & 310 & $-\cdots$ & 315 & 430 & 310 & 430 & 120 \\
\hline 2 & 320 & 480 & 360 & 430 & 340 & - & 330 & 440 & 340 & 450 & 110 \\
\hline 0.05 & 370 & 500 & 420 & 540 & 440 & - . & 390 & 480 & 390 & 510 & 120 \\
\hline
\end{tabular}


$100 \mathrm{~cm}$ (or $15 \mathrm{ppm} \cdot \mathrm{m}^{-1}$ ) (Uchijima et al. 1967) and about $3 \mathrm{ppm} / 15 \mathrm{~cm}$ (or $20 \mathrm{ppm} \cdot \mathrm{m}^{-1}$ ) (Denmead, 1969) respectively. The extremely small gradient of $\mathrm{CO}_{2}$ concentration in the forest may be attributable to a small $\mathrm{CO}_{2}$ assimilation rate per unit space due to the very small leaf area density of the forest as compared with those in stands of agricultural crops.

The isopleth of the concentration above and within forest is shown in Fig. 6-c. It shows that there are two sinks and three sources of $\mathrm{CO}_{2}$ flux in the forest. One sink is at the top of canopy and another in a lower layer. One of the sources is the atmosphere above canopy, and the others are the soil and litter at ground level and the middle layer of the forest. Lemon et al. (1970) pointed out the same phenomenon in a Costa Rican rain forest.

\section{Primary production of the forest}

(1) $\mathrm{CO}_{2}$ flux above forest

In Fig. 11 the diurnal changes of solar radiation and carbon dioxide flux on Nov. 21, 1973 are shown. The estimated values of gross and net photosynthesis are also given in Fig. 11. The light-photosynthesis curve for the forest canopy is given in Fig. 12 based on the results of Nov. $19 \sim 21$. The curve in Fig. 12 represents the mean of results with storage heat at its maximum and with no storage heat.

Lemon et al. (1970) reported that the photosynthesis and respiration rates of a Costa Rican rain forest were about $1 / 10$ of the peak rates observed in temperate forests (Table 4) and crop communities. Our values are larger than theirs but similar to that of a rice community in Japan (Yabuki et al. 1974). The $\mathrm{CO}_{2}$ flux and the net photosynthesis were about $35 \mathrm{mgCO} \cdot 100 \mathrm{~cm}^{-2} \cdot \mathrm{hr}^{-1}$ (97 $\times 10^{-9} \mathrm{gCO}_{2} \cdot \mathrm{cm}^{-2} \cdot \mathrm{sec}^{-1}$ ) and $43 \mathrm{mgCO} 2 \cdot 100 \mathrm{~cm}^{-2} \cdot \mathrm{hr}^{-1}$ $\left(119 \times 10^{-9} \mathrm{gCO}_{2} \cdot \mathrm{cm}^{-2} \cdot \mathrm{sec}^{-1}\right)$ respectively when incoming solar radiation was $1.3 \mathrm{cal} \cdot \mathrm{cm}^{-2} \cdot \mathrm{min}^{-1}$. As the outgoing $\mathrm{CO}_{2}$ flux during night was $15 \mathrm{mgCO}_{2} \cdot 100 \mathrm{~cm}^{-2}$. $\mathrm{hr}^{-1}$, the respiration of aboveground vegetation was $6.6 \mathrm{mgCO} 2 \cdot 100 \mathrm{~cm}^{-2} \cdot \mathrm{hr}^{-1}\left(18 \times 10^{-9} \mathrm{gCO}_{2} \cdot \mathrm{cm}^{-2} \cdot \mathrm{sec}^{-1}\right)$.

\section{(2) Primary production rate}

The carbon dioxide uptake and the primary production rate by Pasoh Forest were estimated from the lightphotosynthesis curve in Fig. 12, the mean intensity of incoming solar radiation and the coefficient of conversion from carbon dioxide to the dry matter $(0.56 \mathrm{gD}$.W. $\mathrm{gCO}_{2}^{-1}$ ) based on the carbon content analysis by

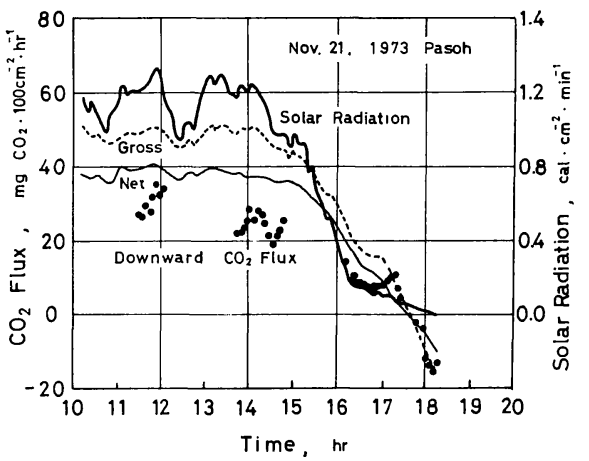

Fig. 11 Diurnal courses of downward $\mathrm{CO}_{2}$ flux and solar radiation on Nov. 21, 1973.

Gross (-----) and net photosynthesis (-) estimated from the curve in Fig. 12.

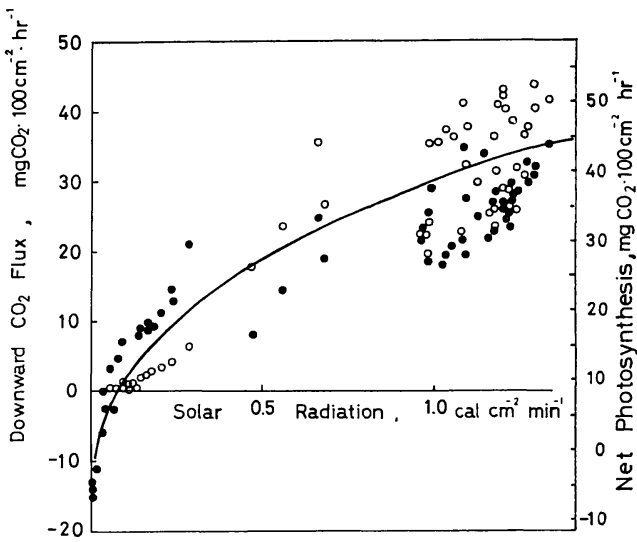

Fig. 12 Relation between downward $\mathrm{CO}_{2}$ flux, net photosynthesis and solar radiation on Nov. 19 21, 1973.

Open circles show results when storage heat is ignored and filled circles show those when storage heat is at its maximum.

Table 4 Comparison of canopy photosynthesis in various forests.

\begin{tabular}{|c|c|c|c|}
\hline & & \multicolumn{2}{|c|}{$\times 10^{-9} \mathrm{mgCO}_{2} \cdot \mathrm{cm}^{-2} \cdot \mathrm{sec}^{-1}$} \\
\hline & $\begin{array}{c}70 \mathrm{Yr}^{*} \\
\text { spruce } \\
\text { (Germany) }\end{array}$ & $\begin{array}{c}40 \mathrm{Yr}^{*} \\
\text { jungle } \\
\text { (Costa Rica) }\end{array}$ & $\begin{array}{l}\text { Pasoh Forest } \\
\text { (W. Malaysia) }\end{array}$ \\
\hline $\begin{array}{l}\text { Solar radiation } \\
\mathrm{cal} \cdot \mathrm{cm}^{-2} \cdot \mathrm{min}^{-1}\end{array}$ & 1.1 & 1.3 & 1.3 \\
\hline Date & $\begin{array}{c}12 \\
\text { Aug. } 66\end{array}$ & $\begin{array}{c}15 \\
\text { Nov. } 67\end{array}$ & $\begin{array}{c}21 \\
\text { Nov.73 }\end{array}$ \\
\hline Photosynthesis & 200 & 35 & 97 \\
\hline $\begin{array}{l}\text { Respiration } \\
\text { Plant } \\
\text { ground }\end{array}$ & $\left.\begin{array}{l}30 \\
50\end{array}\right\} 80$ & $\left.\begin{array}{l}2.6 \\
3.1\end{array}\right\} 5.7$ & $\left.\begin{array}{l}18 \\
23 * * *\end{array}\right\} 41$ \\
\hline Method** & EB.MB & $\mathrm{MB}$ & $\mathrm{EB}$ \\
\hline Author & Baumgartner & Lemon et al & \\
\hline
\end{tabular}

* after Lemon et al. (1970)

** EB: Energy Balance, MB: Momentum Balance.

*** after Ogawa (1974) and Yoneda et al. (1975) 
Yoneda et al. (1975).

Budyko (1968) estimated the mean diurnal solar radiation in West Malaysia at $333 \mathrm{cal} \cdot \mathrm{cm}^{-2} \cdot \mathrm{day}^{-1}$. Soepadmo $(1973,1974)$ reported that the mean daily incoming solar radiations of Pasoh Forest were 359 and $347 \mathrm{cal} \cdot \mathrm{cm}^{-2} \cdot \mathrm{day}^{-1}$ in 1972 and 1973 respectively. We also measured solar radiation at Kuala Pilah about $30 \mathrm{~km}$ apart from Pasoh Forest from Oct. 16 to Nov. 26, 1973. The maximum was $522 \mathrm{cal} \cdot \mathrm{cm}^{-2} \cdot \mathrm{day}^{-1}$, the minimum was $182 \mathrm{cal} \cdot \mathrm{cm}^{-2} \cdot \mathrm{day}^{-1}$, and the mean was $356 \mathrm{cal}$. $\mathrm{cm}^{-2} \cdot \mathrm{day}^{-1}$. Here the value $347 \mathrm{cal} \cdot \mathrm{cm}^{-2} \cdot \mathrm{day}^{-1}$ (Soepadmo, 1974) is used for the estimation of primary production. If the diurnal course of incoming solar radiation $\left({ }_{m} I_{H}\right)$ obeys a sine-curve, we get the next formula for it when the mean daily radiation is $347 \mathrm{cal}$. $\mathrm{cm}^{-2} \cdot \mathrm{day}^{-1}$

$$
{ }_{m} I_{H}=0.97 \sin \left(\frac{\pi}{12} \cdot t\right) \mathrm{cal} \cdot \mathrm{cm}^{-2} \cdot \mathrm{min}^{-1}
$$

where $t$ is the time measured from $0600 \mathrm{hr}$.

Using this relation along with the curve in Fig. 12, the annual gross production and the annual net production were estimated at 81 tonD.W.h $\mathrm{ha}^{-1} \cdot$ year $^{-1}$ and 49 ton D.W.ha ${ }^{-1} \cdot$ year $^{-1}$ respectively (Table 5). The value of annual gross production is almost equal to the estimation for the same forest made by Yoda et al. (1975) using the summation method, although our value of

Table 5 Estimation of primary production of Pasoh Forest.

Whole day gross uptake of $\mathrm{CO}_{2} \quad$ Whole day net uptake of $\mathrm{CO}_{2}$ (Whole day gross photosynthesis) (Whole day net photosynthesis)

$$
\begin{gathered}
{ }_{w} P_{g} \\
396 \mathrm{kgCO}_{2} \cdot \mathrm{ha}^{-1} \cdot \mathrm{day}^{-1} \\
145 \mathrm{tonCO}_{2} \cdot \mathrm{ha}^{-1} \cdot \mathrm{yr}^{-1} \\
81 \mathrm{tonD} \cdot \mathrm{W} \cdot \mathrm{ha}^{-1} \cdot \mathrm{yr}^{-1} \\
\text { solar energy conversion } \\
\text { efficiency }=3.0 \%
\end{gathered}
$$

$158 \mathrm{kgCO}_{2} \cdot \mathrm{ha}^{-1} \cdot$ day $^{-1}$
Whole day plant respiration ${ }_{w} C_{r}$ 58 tonCO $2 \cdot \mathrm{ha}^{-1} \cdot \mathrm{yr}^{-1}$ 32 tonD.W. ha ${ }^{-1} \cdot \mathrm{yr}^{-1}$ ${ }_{w} P_{n}$ $238 \mathrm{kgCO}_{2} \cdot \mathrm{ha}^{-1} \cdot \mathrm{day}^{-1}$ 87 ton $\mathrm{CO}_{2} \cdot \mathrm{ha}^{-1} \cdot \mathrm{yr}^{-1}$ 49 tonD.W. ha $^{-1} \cdot \mathrm{yr}^{-1}$ solar energy conversion efficiency $=1.8 \%$

Whole day soil respiration ${ }_{w} C_{S}$ $202 \mathrm{kgCO}_{2} \cdot \mathrm{ha}^{-1} \cdot \mathrm{day}^{-1}$ 74 ton $\mathrm{CO}_{2} \cdot \mathrm{ha}^{-1} \cdot \mathrm{yr}^{-1}$ 41 tonD.W. ha ${ }^{-1} \cdot \mathrm{yr}^{-1}$

mean incoming solar radiation $=347 \mathrm{cal} \cdot \mathrm{cm}^{-2} \cdot \mathrm{day}^{-1}$ (after Soepadmo, 1974)

${ }_{w} C_{S}={ }_{d} C_{S}={ }_{n} C_{S}=8.4 \mathrm{mgCO} 2 \cdot 100 \mathrm{~cm}^{-2} \cdot \mathrm{hr}^{-1}$ (after Ogawa, 1974 and Yoneda et al., 1975)

The coefficient of conversion from $\mathrm{CO}_{2}$ uptake into the dry matter $=0.56 \mathrm{~g}$ Dry Weight. $\mathrm{gCO}_{2}^{-1}$

(based on the carbon content analysis by Yoneda et al., 1975)

The coefficient of conversion from dry matter into energy $=4.7 \times 10^{3}$ cal.g D.W. ${ }^{-1}$ (Leith, 1968) annual net production is about twice theirs. Since the annual soil respiration is 41 tonD.W. ha ${ }^{-1} \cdot$ year $^{-1}$ (Ogawa, 1974 and Yoneda et al., 1975), the annual increment of dry weight is 8 tonD.W. ha ${ }^{-1} \cdot$ year $^{-1}$. The efficiencies of solar energy conversion for the annual gross and net production are $3.0 \%$ and $1.8 \%$ respectively, using the coefficient of conversion from dry matter into the energy, $4.7 \times 10^{3}$ cal.gD.W. ${ }^{-1}$ (Lieth, 1968).

\section{Acknowledgements}

We would like to thank Prof. T. Kira, Prof. H. Ogawa, and Dr. K. Yoda of Osaka City University for their advices, Dr. R. Sunderland, School of Agriculture, University of Nottingham, for his assistance and equipment preparations and Mr. T. Abe of the University of the Ryukyus for his assistance in the measurement. We also thank Dr. S. Takami of Tokyo University for his helpful comments on the manuscript and Miss M. Sakaguchi for typewriting.

\section{References}

1) Allen, Jr., L.H., Lemon, E. and Müller, L. 1972: Environment of a Costa Rican Forest. Ecology, 53, 102-111.

2) Baumgartner, A. 1969: Meteorological approach to the exchange of $\mathrm{CO}_{2}$ between the atmosphere and vegetation, particularly forest stands. Photosynthetica, 3, 127-149.

3) Baynton, H.W., Biggs, W.G., Hamilton, Jr., H.L., Sherr, P.E. and Worth, J.J.B. 1965a: Wind structure in and above a tropical forest. J. Appl. Meteorol., 4, 670-675.

4) Baynton, H.W., Hamilton, Jr., H.L., Sherr, P.E. and Worth, J.J.B. 1965b: Temperature structure in and above a tropical forest. Quart. J. Roy. Meteorol. Soc., 91, 225-232.

5) Budyko, M.I. 1968: Solar radiation and the use of it by plant. In Agroclimatological Method. Proceeding of the Reading Symposium. UNESCO. 39-53.

6) Denmead, O.T. 1969: Comparative micrometeorology of a wheat field and a forest of Pinus radiata. Agr. Meteorol., 6, 357-371.

7) Eckardt, F.E., Heim, G., Methy, M., Saugier, B. and Sauvenzon, R. 1971: Fonctionnement d'un écosystemè au niveau de la production primare measures effectuées dan une culture d'Helianthus annuus. Ecol. Plant., 6, 51-100.

8) Hales, W.B. 1949: Micrometeorology in the tropics. Bull. Meteorol. Soc., 30, 124-137. 
9) Hosker, Jr., R.P., Nappo, Jr., C.J. and Hanna, S.R. 1974: Diurnal variation of vertical thermal structure in a pine plantation. Agr. Meteorol., 13, 259-265.

10) Kato, R., Tadaki, Y. and Ogawa, H. 1974: Plant biomass and growth increment studies in Pasoh Forest. IBP-Synthesis Meeting, Kuala Lumpur. 12th - 18th, August, 1974.

11) Lemon, E., Allen, Jr., L.H. and Müller, L. 1970: Carbon dioxide exchange of a tropical rain forest. Part II. BioScience, 20, 1054-1059.

12) Lieth, H. 1968: The measurement of calorific values of biological material and the determination of ecological efficiency. In Functioning of Terrestrial Ecosystems at the Primary Production Level (F.E. Eckardt ed.), UNESCO, Paris, 179-186.

13) Ogawa, H. 1974: Litter Production and carbon cycling in Pasoh Forest. IBP-Synthesis Meeting, Kuala Lumpur. 12th - 18th, August, 1974.

14) Soepadmo, E. 1973: Progress report (1970-1972) on IBP-PT Project at Pasoh, Negri Sembilan, Malaysia. In Proceedings of the East Asian Regional Seminar for the International Biological Programme, Kyoto, 1973, (S. Mori and T. Kira ed.), 29-39.

15) Soepadmo, E. 1973: Annual report for 1972. IBPPT. Pasoh Project, Negri Sembilan, Malaysia.

16) Soepadmo, E. 1974: Annual report for 1973. IBPPT. Pasoh Project, Negri Sembilan, Malaysia.

17) Stoller, J. and Lemon, E. 1963: The energy budget at the earth's surface. II. Production and Research Rept. USDA Washington.

18) Takeda, K. 1964: Turbulence in plant canopies. J. Agri. Meteorol., 20, 1-5.

19) Uchijima, Z., Udagawa, T., Horie, T. and Kobayashi, K. 1967: Studies of energy and gas exchange within crop canopies (1) $\mathrm{CO}_{2}$-environment in a corn plant canopy. J. Agri. Meteorol., 23, 99-108.

20) Yabuki, K., Aoki, M. and Hamotani, K. 1974: Studies on the effect of wind speed on photosynthesis. (5) The relation between wind speed and photosynthesis of rice plant community. J. Agri. Meteorol., 30, 101-105.

21) Yabuki, K. and Aoki, M. 1973: Micrometeorology of Minamata evergreen oak forest. In The Interim Report of JIBP-PT-F. March 1973, (T. Shidei ed.), 154-164. (in Japanese)

22) Yoda, K. 1974: Three-dimensional distribution of light intensity in a tropical rain forest of West Malaysia. Jap. J. Ecol., 24, 247-254.

23) Yoda, K., Ogawa, H. and Kira, T. 1975: Structure and productivity of a tropical rain forest in West Malaysia. Read in the 12th International Botanical Congress (Leningrad).

24) Yoneda, T., Yoda, K. and Kira, T. 1975: Accumulation and decomposition of wood litter in Pasoh Forest, West Malaysia. Jap. J. Ecol., 25, (in preparation).

\title{
西マレーシアの熱帯多雨林の微気象 および光合成
}

\author{
青木正敏 ${ }^{* *}$ 矢吹万寿*. 小山弘道 ${ }^{* * *}$ \\ $\left(\begin{array}{c}* * \text { 大阪府立大学農学部環境調節工学研究室, } \\ \text { 百舌鳥梅町 } \\ * * * \text { 大阪市立大学理学部付属植物園, }\end{array}\right.$
}

要約

西マレーシアの熱帯多雨林の微気象の測定および一次生産量の推定を行ない次のような結果が得られた。

日射量は $47 \mathrm{~m}$ の林層のうち上部から $5 \mathrm{~m}$ の林層で約 $50 \%$ となり, 約 $3 \%$ だげ地表面に達した。地表面付近では 気温の日較差は小さく, また相対湿度は常に $90 \%$ 以上であった。夜間でも森林から上空への上向きの水蒸気輸送の あることが観測された。この現象は早朝森林上に見られた霧の発生と関係しているようである。気温, 水蒸気張力お よび $\mathrm{CO}_{2}$ 濃度の林内垂直傾度は非常に小さいが, これはこの森林の小さな葉面積密度のためと考えられる。正味光合 成量は $1.3 \mathrm{cal} \cdot \mathrm{cm}^{-2} \cdot \mathrm{min}^{-1}$ の日射の場合, 約 $43 \mathrm{mg} \mathrm{CO}_{2} \cdot 100 \mathrm{~cm}^{-2} \cdot \mathrm{hr}^{-1}$ であった。年総光合成量は乾物換算で 81 ton Dry Weight·ha ${ }^{-1} \cdot \mathrm{year}^{-1}$ と推定され, その太陽エネルギー変換効率は $3.0 \%$ と推定された。 